\author{
$\mathbb{1}$ Norræna \\ ráðherranefndin
}

\title{
Norræn áætlun um að draga úr umhverfisáhrifum plasts
}

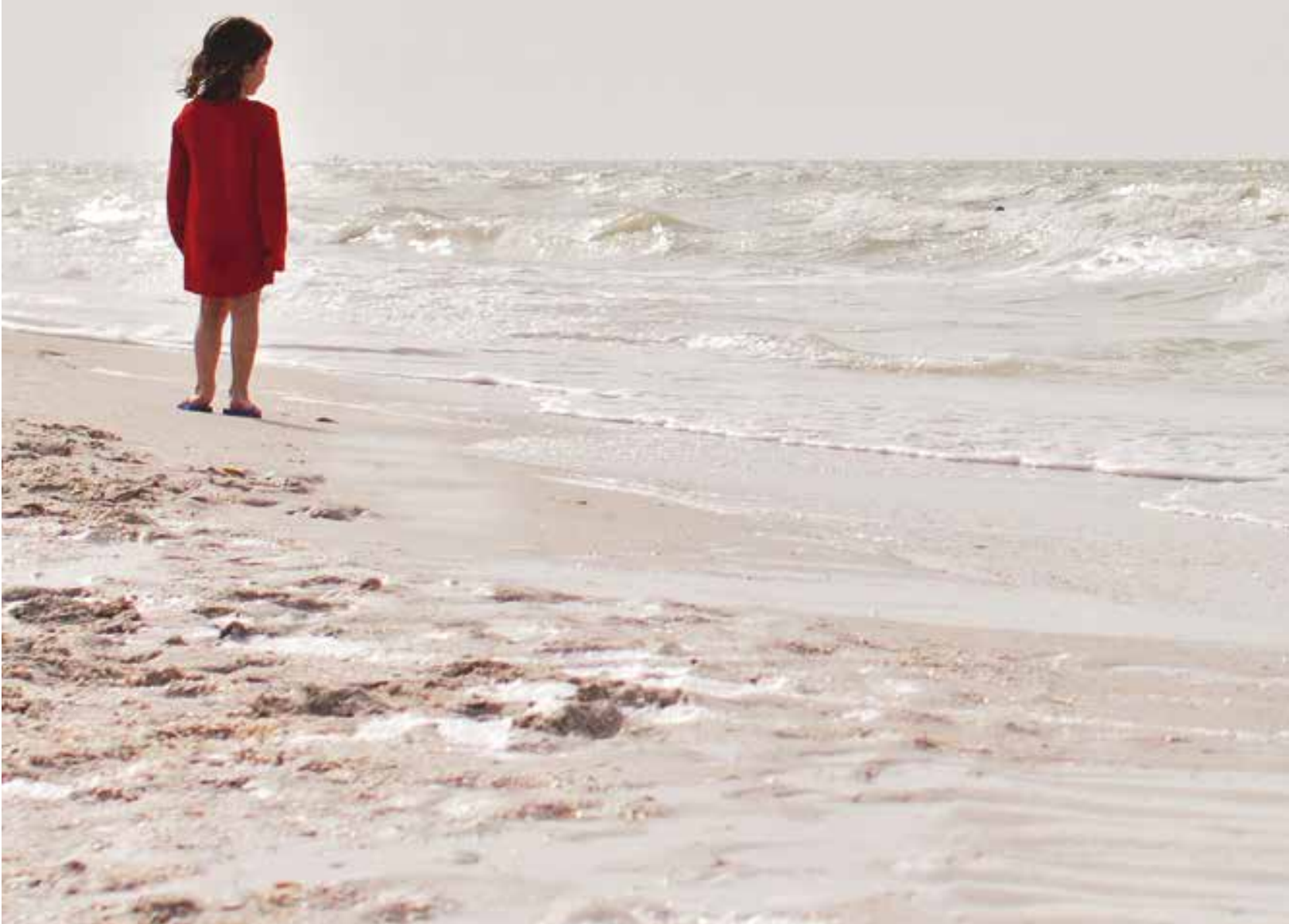




\section{Norræn áætlun um aơ draga úr umhverfisáhrifum plasts}

ISBN 978-92-893-5109-6 (PRINT)

ISBN 978-92-893-5111-9 (PDF)

ISBN: 978-92-893-5110-2 (EPUB))

http://dx.doi.org/10.6027ANP2017-751

ANP 2017:751

(c) Norræna ráơherranefndin 2017

Umbrot: Gitte Wejnold

Kápumynd: Scanpix.dk

\section{Norrænt samstarf}

Norræna samstarfið er eitt umfangsmesta svæðasamstarf í

heiminum. Samstarfið byggir á landfræðilegri legu landanna, sameiginlegri sögu peirra og menningu. Að samstarfinu koma Danmörk, Finnland, Ísland, Noregur og Svípjóð auk Álandseyja, Færeyja og Grænlands.

Norræna samstarfið er pólitískt, efnahagslegt og menningarlegt og skiptir miklu í evrópsku og alpjóðlegu samstarfi. Löndin vinna saman að pví að marka Norðurlöndum stöðu í öflugri Evrópu.

Með norrænu samstarfi er unnið að pví að gæta hagsmuna svæðisins og efla norræn gildi í hnattrænum heimi. Sameiginleg gildi landanna styrkja stöðu Norðurlanda og skipa peim meðal peirra svæða í heiminum par sem nýsköpun og samkeppnishæfni er mest.

\section{Norræna ráőherranefndin}

Nordens Hus

Ved Stranden 18

DK-1061 København K

www.norden.org

Sækja útgefið efni: www.norden.org/nordpub 


\section{Norræn áætlun um að draga úr umhverfisáhrifum plasts}





\section{EFNISYFIRLIT}

Norræn ráðherrayfirlýsing um að draga úr umhverfisáhrifum plasts

1. Kynning

2. Fyrirbyggjandi aðgerðir gegn myndun plastúrgangs og stuðningur við hönnun sem stuðlar að aukinni endurnotkun og endurvinnslu á plasti og lengri líftíma plasthluta

3. Árangursrík kerfi fyrir meðhöndlun úrgangs og aukin endurvinnsla plastúrgangs

4. Samstarf um aðgerðir til að stöðva myndun plastúrgangs í höfum og finna hagkvæmar hreinsunarlausnir

5. Að efla pekkingu á plastögnum og greina aðgerðir til að draga úr losun peirra út í umhverfið

6. Að efla pekkingu á umhverfisáhrifum lífgrundaðra efna og lífbrjótanlegs plasts í samanburði við hefðbundin plastefni

7. Að efla pekkingu á skaðlegum efnum sem notuð eru við endurvinnslu plasts 


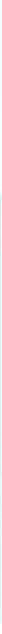

\section{Norræn ráôherrayfirlýsing um að̃ draga úr umhverfisáhrifum plasts}

Við, norrænu umhverfisráðherrarnir, höfum í dag, 2. maí 2017, ákveðið að ýta úr vör norrænni áætlun um að draga úr umhverfisáhrifum plasts.

Neikvæð umhverfisáhrif af völdum plasts eru norrænu löndunum mikið áhyggjuefni. Plast er sú tegund úrgangs sem kemur oftast fyrir og í mestu magni í umhverfi sjávar. Magn plastúrgangs og plastagna í sjó fer ört vaxandi og er alvarleg ógn við umhverfi og vistkerfi sjávar og vistkerfapjónustu í hverju norrænu landanna, á Norðurlöndum sem svæði, innan Evrópusambandsins og á alpjóðavísu. Skaðleg efni í plasti geta haft áhrif á heilsu manna og á umhverfið, og í peim getur falist áskorun fyrir öruggt hringrásarhagkerfi plasts. Framleiðsla plasts sem hefur olíu að undirstöðuefni og förgun pess með brennslu á pátt í að stuðla að loftslagsbreytingum.

Norðurlöndin leitast við að hvetja til og efla sjálfbæra nálgun á framleiðslu og notkun plasts og meðhöndlun og endurvinnslu plastúrgangs. Sameiginleg framtíðarsýn okkar er að plast verði framleitt, notað og endurunnið án pess að af hljótist áhrif á loftslag jarðar eða áhætta fyrir heilsu manna og umhverfið, og pví verði varnað að plastúrgangur og plastagnir rati í umhverfi sjávar, stöðuvötn og ár.

Plast er endingargott og panpolið efni sem nýtt er í allt frá fatnaði til bifreiða. Léttleiki plasts er orkusparandi og sem innihaldsefni umbúða getur pað varið 
Sameiginleg framtíðarsýn okkar er að plast verði framleitt, notað og endurunnið án pess að af hljótist áhrif á loftslag jarðar eða áhætta fyrir heilsu manna og umhverfið, og pví verði varnað að plastúrgangur og plastagnir rati í umhverfi sjávar, stöðuvötn og ár.

matvæli og aðra verðmæta vöru. Pau alvarlegu neikvæðu umhverfisáhrif sem hljótast af framleiðslu, notkun og förgun plasts liggja pó einnig í augum uppi.

Til að tryggja sjálfbæra framleiðslu, neyslu og endurvinnslu á plasti kalla norrænu umhverfisráðherrarnir nú eftir aðgerðum á alpjóðlegum, norrænum og landsbundnum vettvangi og á vettvangi Evrópusambandsins. Norræna áætlunin verður stefnumótunartæki til að auka pekkingu, leggja drög að aðgerðum og stuðla að vitundarvakningu í norrænum samstarfsnetum. Norræna áætlunin um að draga úr umhverfisáhrifum plasts mun styðja við framtíðarsýn okkar á fjölmörgum sviðum stefnumótunar, m.a. pað að varna pví að plastúrgangur og plastagnir rati út í umhverfið og höfin, stuðla að bættri endurvinnslu og meta umhverfisáhrif lífbrjótanlegs plasts og annarra valkosta sem gætu nýst í stað hefðbundins plasts, auk pess að auka pekkingu á innihaldsefnum plasts.

Áætlunin er fyrst og fremst ætluð til samstarfs milli Norðurlandanna og verður hrint í framkvæmd á vegum Norrænu ráðherranefndarinnar. Einnig mun hún styðja við tengda starfsemi utan Norðurlanda, til að byrja með metnaðarfulla innleiðingu á 12. og 14. markmiði Sameinuðu pjóðanna um sjálfbæra próun, að meðtöldu undirmarkmiðinu 14.1 um rusl í sjó. Ennfremur er áætlunin til marks um stuðning Norðurlanda við innleiðingu sampykktar $1 / 6$ frá Umhverfisráðstefnu Sameinuðu pjóðanna (UNEA) ("Marine plastic debris and microplastics") og sampykktar 2/11 ("Marine plastic litter and microplastics"), auk verkefna sem heyra undir svæðisbundnar sampykktir á sviðinu. Áætlunin er einnig liður í framlagi Norðurlanda til Clean Seas, átaks Umhverfisáætlunar Sameinuðu pjóðanna (UNEP) gegn úrgangi í hafi. 


\section{Kynning}

Norræna áætlunin um að draga úr umhverfisáhrifum plasts er stefnumótunartæki til að auka pekkingu, leggja drög að aðgerðum og stuðla að samlegðaráhrifum, samstarfsnetum og vitundarvakningu á Norðurlöndum. Áætlunin tekur til tímabilsins 2017-2018 og henni verður hrint í framkvæmd innan ramma Norrænu ráðherranefndarinnar.

Norræna ráðherranefndin á sér langa sögu samstarfs um málefni plasts, sem miðar að pví að auka pekkingu á aðferðum og kerfum við flokkun, söfnun og endurvinnslu plasts og framkvæma úrbætur á verðmætakeðjunni. Annað mikilvægt svið í norrænu samstarfi hefur snúið að plastúrgangi í umhverfi sjávar, par með töldum plastögnum. Áætlunin um að draga úr umhverfisáhrifum plasts mun byggja á peim niðurstöðum sem pessar aðgerðir hafa skilað.

Áætlunin mun styðja við norrænu löndin í viðleitni peirra til að fyrirbyggja myndun plastúrgangs, auka endurnotkun og endurvinnslu á plasti, greiða fyrir innleiðingu hringrásarhagkerfis og halda plastúrgangi og plastögnum í umhverfi sjávar í lágmarki. Norrænu áætluninni um að draga úr umhverfisáhrifum plasts er ennfremur ýtt úr vör samsíða fjölmörgum alpjóðlegum átaksverkefnum sem nú standa yfir á pessu sviði, og mun hún styðja við framkvæmd peirra.
Undir áætlunina heyra sex stefnumótandi svið fyrir norrænt samstarf um sjálfbæra plastnotkun. Viðeigandi markmið hafa verið sett á öllum sviðunum sex. Hin stefnumótandi svið eru:

1. Fyrirbyggjandi aðgerðir gegn myndun plastúrgangs og stuðningur við hönnun sem stuðlar að aukinni endurnotkun og endurvinnslu á plasti og lengri líftíma plasthluta

2. Árangursrík kerfi fyrir meðhöndlun úrgangs og aukin endurvinnsla plastúrgangs

3. Samstarf um aðgerðir til að stöðva myndun plastúrgangs í höfum og finna hagkvæmar hreinsunarlausnir

4. Að efla pekkingu á plastögnum og greina aðgerðir til að draga úr losun peirra út í umhverfið

5. Að efla pekkingu á umhverfisáhrifum lífgrundaðra efna og lífbrjótanlegs plasts í samanburði við hefðbundin plastefni

6. Að efla pekkingu á skaðlegum efnum sem notuð eru við endurvinnslu plasts 


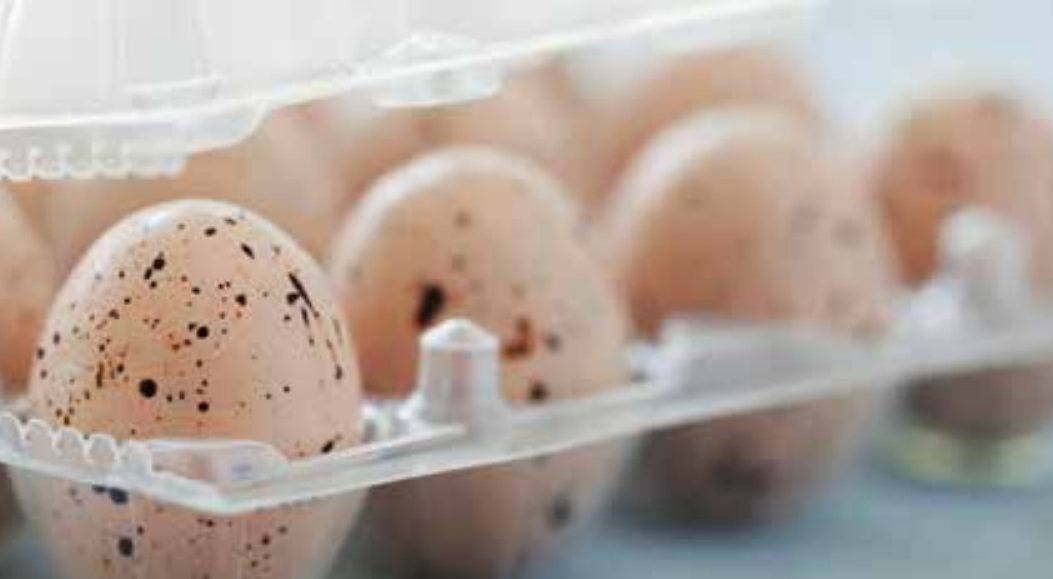

Hverju og einu markmiði á hinum stefnumótandi sviðum samstarfsins verður mætt með einu verkefni að lágmarki.

\section{Framkvæmd}

Starfsemi og verkefni sem falla undir plastáætlunina verða fyrst og fremst fjármögnuð af Norrænu ráðherranefndinni og peim hrint í framkvæmd á vegum hennar. Norræna embættismannanefndin um umhverfismál mun bera meginábyrgð á áætluninni. Norrænir vinnuhópar munu hafa umsjón með framkvæmd allrar starfsemi á vegum áætlunarinnar. Utanaðkomandi samstarfsaðilar, svo sem landsbundin yfirvöld, rannsóknastofnanir, iðnaðarstofnanir og félagasamtök munu pó einnig koma að áætluninni. 


\section{Fyrirbyggjandi að̆gerð̄ir gegn myndun plastúrgangs og stuôningur viơ hönnun sem stuôlar aơ aukinni endurnotkun og endurvinnslu á plasti og lengri líftíma plasthluta}

Mikið af plastúrgangi í nútímasamfélagi má rekja til einnota plasthluta, plasthluta af litlum gæðum og hluta sem innihalda plastefni sem ekki verða endurunnin með góðu móti. Einnig má rekja mikið af rusli í sjó til einnota plasts. Pví parf að leggja áherslu á að fyrirbyggja að plastúrgangur myndist til að byrja með.

Pegar kemur að pví að fyrirbyggja myndun plastúrgangs liggja talsverðir möguleikar í pví að taka upp endurnýtanlegar vörur í stað einnota vara, t.d. með próun nýrra innkaupa- og neyslumynstra. Greina ætti leiðir og aðferðir á viðeigandi stigum til að draga úr notkun einnota plasthluta og fyrirbyggja að peir rati út í umhverfið sem rusl.

\section{Markmið 1}

Norræna áætlunin um að draga úr umhverfisáhrifum plasts eykur pekkingu á einnota hlutum og vörum úr plasti með mjög stuttan líftíma, með pað að markmiði að hjálpa okkur að greina aðgerðir sem stuðla að breytingum á neysluhegðun og framleiðslu og fyrirbyggja myndun plastúrgangs.
Með pví að leggja áherslu á forvarnir gegn úrgangi, fjölnota vörur og lengri líftíma í hönnunarferli plastvara, vara sem innihalda plasthluta og vörukerfa, má draga úr magni plastúrgangs svo um munar. Til að auka endurvinnanleika, sem lið í umskiptum til hringlaga hagkerfis, parf að gæta pess að fínstilla aðskilnað innihaldsefna í hönnunarferli vara með pví að blanda saman mismunandi gerðum plasts og blanda plastefnum við önnur efni. Plastefni, aukefni og fylliefni parf að velja á grundvelli endurvinnanleika. Auk pess verða viðeigandi upplýsingar, t.d. um mismunandi gerðir plasts og pau aukefni og fylliefni sem plast inniheldur, að vera aðgengilegar til að greiða fyrir endurvinnslu.

\section{Markmið 2}

Norræna áætlunin um að draga úr umhverfisáhrifum plasts eykur bekkingu á pví hvernig fella má forvarnir gegn plastúrgangi betur inn í hönnunarferli tiltekinna vara, og hvernig efla má viðskiptalíkön sem byggja á hringrásarhagkerfi og styðja endurnotkun, lengri líftíma og endurvinnslu. 


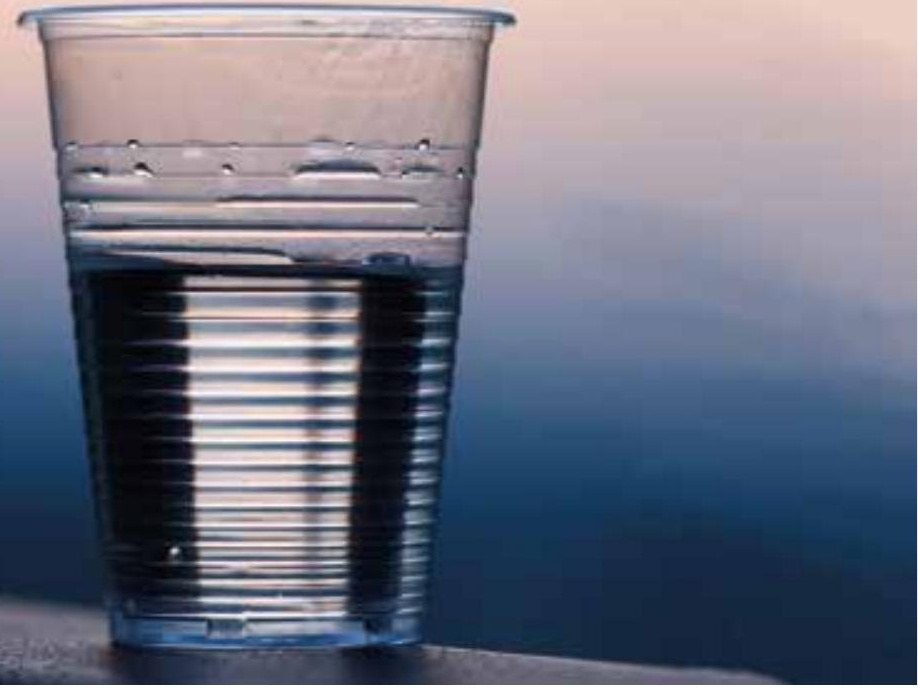

Með pví að leggja áherslu á forvarnir gegn úrgangi, fjölnota vörur og lengri líftíma í hönnunarferli plastvara, vara sem innihalda plasthluta og vörukerfa, má draga úr magni plastúrgangs svo um munar.

\section{Markmið 3}

Norræna áætlunin um að draga úr umhverfisáhrifum plasts mun stuðla að próun ramma fyrir vistvæna hönnun með áherslu á að sjónarmið endurvinnslu plastúrgangs og forvarna gegn plastúrgangi verði tekin með í reikninginn.

Plast er algengt innihaldsefni í vörum og vöruumbúðum vegna fjölbreytilegs notagildis pess. Prátt fyrir pau neikvæðu umhverfisáhrif sem hljótast af plastframleiðslu og meðhöndlun á plastúrgangi getur plastnotkun einnig haft jákvæð áhrif, t.d. vegna léttleika plastsins og pess hve hentugt pað er til að verja vörur. Í mörgum vöruflokkum er pó unnt að varna pví að plastúrgangur myndist með pví að taka upp notkun annarra hentugra efna pess í stað. Til dæmis er örplast notað í margar snyrtivörur og hreinlætisvörur, par sem nota mætti önnur efni sem hefðu minni áhrif á umhverfið. Norræna umhverfismerkið Svanurinn veitir nú pegar staðfestingu á pví að örplast sé ekki að finna í viðkomandi vöru. 


\section{3. Árangursrík kerfi fyrir meơhöndlun úrgangs og aukin endurvinnsla plastúrgangs}

Norðurlöndin líta á aukna endurvinnslu plastúrgangs og notkun endurunninna plastefna sem nauðsyn. Loka parf hringrás plastsins í hringrásarhagkerfi og tryggja endurvinnanleika pess, en hvort tveggja myndi minnka líkur á bví að plastúrgangur rataði út í umhverfið og draga úr umhverfisáhrifum sem tengjast notkun pess og framleiðslu.

Norðurlöndin hafa komið á kerfum fyrir söfnun og endurvinnslu plastúrgangs, en prátt fyrir pað er aðeins tiltölulega lítill hluti plasts á norrænum markaði endurunninn. Enn liggja miklir ónýttir möguleikar í pví að endurvinna plast úr vörum og umbúðum. Áætlað er að unnt væri að endurvinna allt að 700 púsund tonn af plasti úr blönduðum úrgangi sveitarfélaga á Norðurlöndunum einum.

Nauðsynlegt er að auka færni og bæta tæknilega innviði til að próa núverandi meðhöndlunarkerfi úrgangs til að taka við plasti til endurvinnslu í meiri mæli.

Auka má umfang endurvinnslu með pví að bæta skilvirkni í kerfum til söfnunar og flokkunar. Petta mun einnig kalla á viðleitni til að hanna vörur og vörukerfi sem gera t.d. ráð fyrir að hægt sé að taka plasthluti í sundur, einnig hluti sem eru flóknari að gerð, og koma á kerfum sem einkennast af lítilli efnisnotkun og úrgangsmyndun. Einnig má efla endurvinnslu með pví að votta endurunnið plast, með pví að próa og fjármagna nýskapandi tækni til flokkunar og endurvinnslu og með pví að auka samstarf og bæta samskipti gegnum alla verðmætakeðju plastsins. Í stuttu máli parf að próa aðgerðir gegnum alla pætti verðmætakeðjunnar til að greiða fyrir stöðugu streymi áreiðanlegra og vel skilgreindra endurunninna plastefna af miklum gæðum fyrir neytendur framtíðarinnar. Hér er afar mikilvægt að tryggja aðkomu markaðsaðila, s.s. iðnaðarstofnana.

\section{Markmið 4}

Norræna áætlunin um að draga úr umhverfisáhrifum plasts hvetur til miðlunar á pekkingu og reynslu milli norrænu landanna og eflir aðgerðir sem ætlað er að styðja við skilvirk úrgangsmeðhöndlunarkerfi og markaði fyrir endurunnið plast. 


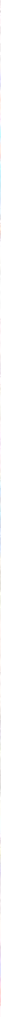

Áætlað er að unnt væri að endurvinna allt að 700 púsund tonn af plasti úr blönduðum úrgangi sveitarfélaga á Norðurlöndunum einum.

Framtíðarfyrirkomulag markaða fyrir endurunnið plast verður að miklu leyti komið undir próun á vettvangi ESB. Plast er eitt fimm forgangssviða í framkvæmdaáætlun ESB fyrir hringrásarhagkerfið.

Framkvæmdaáætlunin inniheldur endurskoðun á tilskipunum ESB um ramma úrgangs og um umbúðir sem tekur til málefna sem tengjast flokkun, söfnun og markmiðum við endurvinnslu plastúrgangs. Væntanleg stefna ESB í plastmálum mun samanstanda af aðgerðum og starfsemi sem miða að pví að auka endurvinnsluhlutfall og draga úr mengun. Norræna áætlunin um að draga úr umhverfisáhrifum plasts mun efla pessa áherslu á plast í hringrásarhagkerfinu á vettvangi ESB. 


\section{Samstarf um aðgerðir til að stöðva myndun plastúrgangs í höfum og finna hagkvæmar hreinsunarlausnir}

Árið 2010 var áætlað að á bilinu 4,8 til 12,7 milljónir tonna af plasti hefðu ratað í sjóinn. Framleiðsla og notkun á plasti er enn að aukast, sem pýðir að magn plasts og plastagna í umhverfinu mun líklega aukast ef við grípum ekki til aðgerða. Áætlað er að núverandi magn plasts í sjónum muni hafa tvöfaldast árið 2030 og fjórfaldast árið 2050. Rannsóknir sýna að plastúrgangur af öllum stærðum er í sjó og vötnum alls staðar í heiminum - allt frá hinum afskekktu norðurslóðum til strandsvæða við stórborgir.

Plastúrgangur í umhverfi sjávar virðir engin landamæri.

Neikvæð áhrif stórra plaststykkja í höfunum leyna sér ekki. Plastið særir, slasar og jafnvel drepur fugla, fiska og spendýr, pað mengar svæði sem ferðalangar og íbúar strandsvæða sækja i frítíma sínum og getur jafnvel verið prándur í götu skipa og báta. Dýr festast og drepast í fiskveiðibúnaði sem hent hefur verið í sjóinn. Plast sem flýtur milli staða kann að flytja með sér skaðlegar og framandi lífverur. Talið er að niðurbrot stórra plaststykkja sé ein helsta uppspretta plastagna í umhverfi sjávar.
Hin miklu gæði norrænna kerfa fyrir meðhöndlun úrgangs halda plastúrgangi að mestu úr höfum okkar og náttúrusvæðum. Pó er plastúrgangur sídur en svo ópekkt vandamál á strandog hafsvæðum okkar. Plastúrgangur í norrænum höfum og stöðuvötnum er hvorttveggja af völdum neytenda og iðnaðar á landi og í sjó. Plastið getur einnig borist um langan veg með hafstraumum. Enn sem komið er skortir okkur nákvæma bekkingu á pví hvaðan pessi plastúrgangur er upprunninn og hvernig hann ratar í höf og vatnsumhverfi.

\section{Markmið 5}

Norræna áætlunin um að draga úr umhverfisáhrifum plasts stuðlar að aukinni pekkingu á uppruna plastúrgangs í höfum og vatnsumhverfi, með pað að markmiði að skapa grundvöll fyrir markvissar fyrirbyggjandi aðgerðir gegn plastúrgangi í sjávar- og vatnsumhverfi.

Á Norðurlöndum búa strandpjóðir með langa reynslu af fiskveiðum, siglingum og öðrum sjávartengdum iðnaði. Aðgerðir til 
að varna bví að fiskveiðibúnaði sé hent í sjó og valdi lífverum par skaða verða $æ$ meira aðkallandi á vettvangi norræns samstarfs.

Plastúrgangur endar á ströndum okkar, sjávarbotni, hafsvæðum, í botnfalli og lífríki hafsins. Rusl í umhverfi sjávar er péttara meðfram ströndum en í úthöfum. Auk pess að draga úr magni úrgangs og tryggja árangursríka meðhöndlun hans, er hreinsun rusls af ströndum hagkvæm leið til að draga úr rusli og plastögnum í höfunum almennt. Borgaraleg samtök á Norðurlöndum vinna í síauknum mæli mikilvægt starf við samhæfingu sjálfboðaliða, og með stuðningi opinberra stofnana má ná umtalsverðum árangri. Við hreinsunaraðgerðir og -átaksverkefni, svo og tækninýjungar og nýjar aðferðir í hreinsun, ætti að leggja áherslu á hagkvæmni út frá bestu pekkingu sem völ er á og reyna að forðast neikvæðar hliðarverkanir á umhverfið.

Aðgerðir til hreinsunar og til að fyrirbyggja útbreiðslu plastúrgangs eru nauðsynlegar á öllum stigum.

\section{Markmið 6}

Norræna áætlunin um að draga úr umhverfisáhrifum plasts eykur pekkingu á hagkvæmum og umhverfisvænum hreinsilausnum fyrir úrgang í sjó og styður hreinsunaraðgerðir borgaralegra samtaka, svæðisbundinna yfirvalda og sjávarútvegs á norrænum strandsvæðum.

\section{Markmið 7}

Norræna áætlunin um að draga úr umhverfisáhrifum plasts eykur pekkingu á og hvetur til pekkingarmiðlunar um reynslu sem tengist forvörnum gegn plastrusli af völdum sjóflutninga, í samstarfi viðð aðila í sjóflutningageira.

Áætlun SP um sjálfbæra próun inniheldur markmið sem miða að pví að útrýma fátækt, vernda jörðina og tryggja öllum velmegun, meðal annars 14. sjálfbærnimarkmiðið ("Líf í vatni"). Í markmiði 14.1 er kallað eftir pví að komið sé í veg fyrir og verulega dregið úr hvers kyns mengun sjávar, par með töldu rusli í sjó, fram að árinu 2025. Sampykktir umhverfisráðstefnu SP frá 2014 og 2016 um plastrusl og plastagnir í sjó eru 
Rannsóknir sýna að plastúrgangur af öllum stærðum er ísjó

og vötnum alls staðar í heiminum - allt frá hinum afskekktu

norðurslóðum til strandsvæða við stórborgir.

leiðbeinandi við að minnka hlutfall hvors

tveggja í umhverfi sjávar.

Í samningum HELCOM (um verndun

Eystrasaltsins) og OSPAR (um

verndun Norðaustur-Atlantshafsins)

eru aðgerðaáætlanir um úrgang í

sjó sem greiða fyrir og leiðbeina um

próun sameiginlegra vísa og tengdra

markmiða, svo og ápreifanlegra aðgerða til að fyrirbyggja og draga úr úrgangi í sjó með pví að taka á meginuppsprettum hans. Pað starf sem unnið verður út frá bessum samningum mun einnig stuðla að pví að uppfylla haftilskipun ESB.
Markmið 8

Með norrænu áætluninni um að

draga úr umhverfisáhrifum plasts tjá Norðurlöndin stuðning sinn við og vilja sinn til að starfa saman að framkvæmd alpjóðlegra og svæðisbundinna sampykkta og aðgerðaáætlana sem miða að pví að̃ draga úr plastúrgangi í höfum og vatnsumhverfi, par á meðal sampykktir og áætlanir sem SP, HELCOM, OSPAR, Norðurskautsráðið og ESB hafa gengist undir, eftir pví sem við á. 


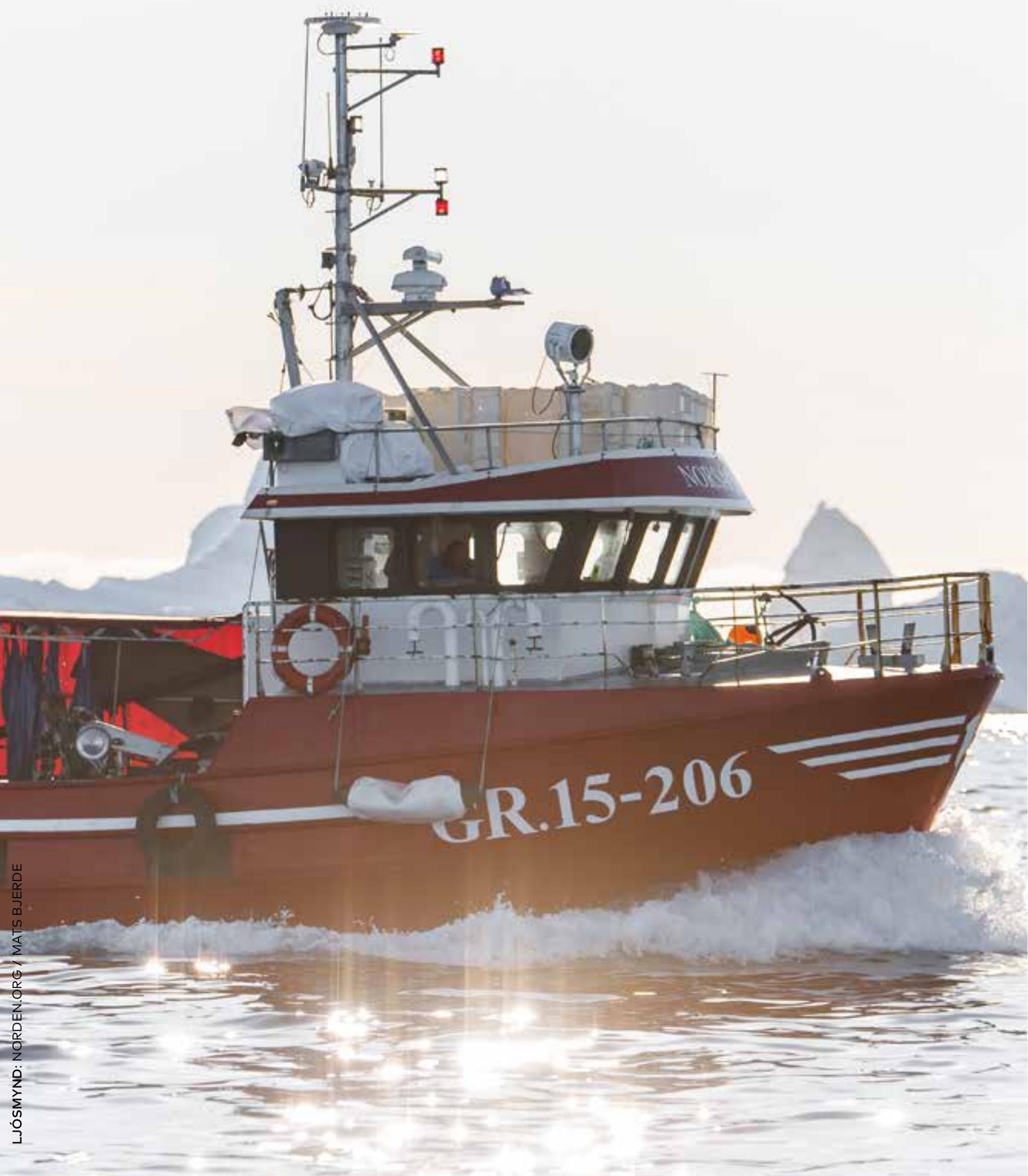




\section{Að̃ efla pekkingu á plastögnum og greina að̃gerðir til aơ draga úr losun peirra út í umhverfio}

Plastagnir leynast víða í umhverfi

okkar, m.a. í jarðvegi og sjávar- og vatnsumhverfi. Plastagnir losna út í

umhverfið með notkun og sliti á vörum á borð við dekk, málningu og vefnaðarvöru, auk pess sem örplasti er vísvitandi bætt við sem innihaldsefni í tilteknar vörur. Í umhverfi sjávar kann ört niðurbrot stærri plaststykkja í plastagnir að skýra misræmið á milli hins mikla magns plastúrgangs sem endar í umhverfi sjávar og vatns, og hins mun minna magns sem unnt hefur verið að greina með vöktunartækni í höfunum. Frekari vöktun mun auka pekkingu á magni, dreifingu og niðurbroti plastagna í höfum og vatnsumhverfi og gera kleift að haga aðgerðum í samræmi við pað.

\section{Markmið 9}

Norræna áætlunin um að draga úr umhverfisáhrifum plasts eykur pekkingu á útbreiðslu og afdrifum plastagna í umhverfinu.
Vitað er að plastagnir geta verið skaðlegar umhverfinu en okkur skortir pekkingu á áhrifum peirra á mannfólk og rándýrin efst í fæðukeðjunni. Óttast er að örsmáar plastagnir geti farið gegnum frumuhimnur og inn í blóðrás og vefi dýra, hugsanlega með skaðlegum afleiðingum. Hingað til hafa niðurstöður rannsókna pó ekki bent til pess að dýr sem hafa innbyrt plastefni séu útsett fyrir skaðlegum efnum í auknum mæli. Fjölmörg alpjóðleg rannsóknaverkefni sem nú standa yfir auka óðum pekkingu á pessum málum, en meiri upplýsinga er pörf.

Fiskveiðar og fiskeldi eru háð aðgengi að hreinu og heilnæmu hráefni. Sívaxandi magn plastúrgangs í sjó, sem brotnar niður í plastagnir sem innbyrtar eru af sjávarlífverum, kann að hafa umtalsverð efnahagsleg og menningarleg áhrif á Norðurlöndin, par sem bláa hagkerfið er pýðingarmikið fyrir vaxtarmöguleika nú og í framtíðinni. 


\section{Pó að pekkingu á útbreiðslu plastagna og áhrifum peirra á umhverfið og lífríki sjávar sé enn ábótavant, er hún engu að síður nægileg til að undirstrika alvarleika núverandi próunar. Varúðarreglan kallar á að við grípum til aðgerða.}

\section{Markmið 10}

Norræna áætlunin um að̃ draga úr umhverfisáhrifum plasts eykur við hina vaxandi pekkingu á áhrifum plastagna á lífríki sjávar, vatnsumhverfi, heilsu manna og sjávartengdar atvinnugreinar.

Pó að pekkingu á útbreiðslu plastagna og áhrifum peirra á umhverfið og lífríki sjávar sé enn ábótavant, er hún engu að síður nægileg til að undirstrika alvarleika núverandi próunar. Varúðarreglan kallar á að við grípum til aðgerða. Hin skilvirku úrgangssöfnunarkerfi Norðurlanda hjálpa til við að halda pví plastmagni sem ratar út í stöðuvötn og höf í lágmarki. Rannsóknir í öllum norrænu löndunum hafa pó sýnt að plastagnir eiga einnig upptök sín á landi, s.s. í dekkjum, á manngerðum ípróttasvæðum og æfingavöllum, í fínkornóttum efnum, við pvott á vefnaðarvöru, í rusli, málningarvörum, snyrtivörum og á meðferðarstöðum úrgangs. Paðan berast plastagnir út í höf og vötn gegnum m.a. skólphreinsistöðvar og regnvatn. Petta pýðir að einnig parf að leggja áherslu á aðgerðir sem miða að pví að draga úr losun plastagna frá pekktum uppsprettum á landi.

\section{Markmið 11}

Norræna áætlunin um að draga úr umhverfisáhrifum plasts eflir aðgerðir og upplýsingamiðlun um reynslu milli Norðurlandanna um að draga úr losun plastagna sem eiga upptök sín á landi.

Eins og stendur eru ekki til neinar alpjóðlega samhæfðar skilgreiningar á plastögnum og rusli í sjó, og ekki hefur verið komist að samkomulagi um aðferðir til að mæla og hafa eftirlit með aðferðum og umhverfisvísum. Petta hamlar skilvirku eftirliti og innleiðingu reglna á hnattræna, svæðisbundna og landsbundna vísu.

\section{Markmið 12}

Norræna áætlunin um að draga úr umhverfisáhrifum plasts styður við próun alpjóðlega samhæfðra skilgreininga, íðorða og aðferða til að mæla og hafa eftirlit með áhrifum af og próun á plastúrgangi og plastögnum í umhverfinu. 


\section{Að̛ efla pekkingu á umhverfisáhrifum lífgrundaðra efna og lífbrjótanlegs plasts í samanburơi viơ hefðbundin plastefni}

Plastframleiðsla veldur losun á um 400 milljónum tonna gróðurhúsalofttegunda árlega (2012). Yfir $90 \%$ af öllu plasti eru framleidd úr jarðefnaeldsneyti. Til lengri tíma litið parf að aftengja plastframleiðslu áður ósnertu jarðefnaeldsneyti. Hægt er að draga úr umhverfisáhrifum af völdum plastúrgangs úr jarðefnaeldsneyti með pví að nota önnur efni í stað plastsins, svo sem pappír og málm. Lífræn plastefni - plast sem framleitt er úr lífgrunduðu hráefni - eru einnig mögulegur valkostur, pó að enn eigi eftir að meta sjálfbærni peirra. Leiðarvísir Framkvæmdastjórnar Evrópusambandsins, „Roadmap for a Strategy on Plastics in a Circular Economy", kallar eftir auknum forvörnum og endurvinnslu, en einnig mati á vænleika og umhverfisáhrifum lífmassa og koltvísýrings sem hugsanlegra uppspretta hráefnis.

Norðurlöndin vilja leggja sitt af mörkum til að efla pekkingu á lífgrunduðum plastefnum og ganga úr skugga um hvort slíkir valkostir séu hagkvæmari fyrir umhverfið en vörur sem hafa olíu að undirstöðuefni, út frá albjóðlegum breytum svo sem koltvísýringslosun, líffræðilegri fjölbreytni og efnafræðilegri mengun. Við slíkt mat verður að hafa hliðsjón af öllu framleiðslu- og notkunarferli vörunnar til að tryggja að aðgerðir hafi ekki öfug áhrif til lengri tíma litið.

Fjölmargir hagsmunaaðilar framkvæma nú mat á framleiðslu- og notkunarferli ýmissa lífgrundaðra plastefna. Niðurstöðurnar munu nýtast í framtíðarstarfi tengdu lífgrunduðum valkostum sem hugsanlega geta komið í stað plasts.

\section{Markmið 13}

Norræna áætlunin um að draga úr umhverfisáhrifum plasts stuðlar að pekkingarsöfnun um og mati á umhverfisáhrifum lífgrundaðra plastefna.

Sumir hlutar lífgrundaðra plastefna og plasts með olíu að undirstöðuefni eru lífbrjótanlegir undir vissum kringumstæðum. Lífbrjótanlegt plast 


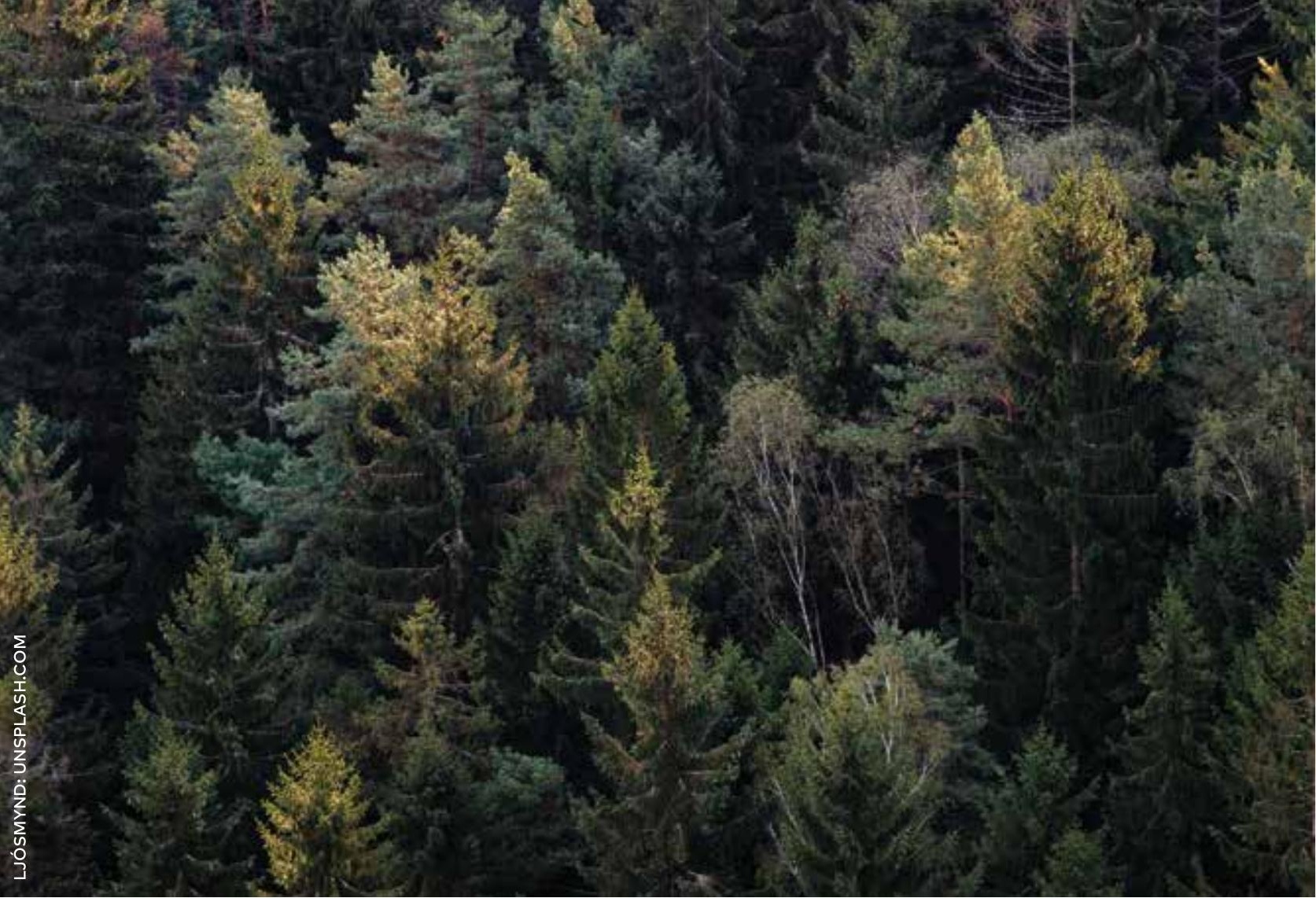

Norðurlöndin vilja leggja sitt af mörkum til að efla pekkingu á lífgrunduðum plastefnum og ganga úr skugga um hvort slíkir valkostir séu hagkvæmari fyrir umhverfið en vörur sem hafa olíu að undirstöðuefni.

kann að henta í sumar vörur sem á að farga úti i náttúrunni frekar en að safna peim, eða í annars konar vörur, s.s. tiltekin smyrsl sem ætluð eru til læknifræðilegra nota. Sé pví blandað við hefðbundin plastefni hamlar lífbrjótanlegt plast pó endurvinnslu plastsins. Einnig er vert að leggja áherslu á að samræmdra skilgreininga og staðla er pörf til að tryggja að lífbrjótanlegt plast brotni niður að fullu undir náttúrulegum kringumstæðum.

\section{Markmið̃ 14}

Norræna áætlunin um að̃ draga úr umhverfisáhrifum plasts eykur pekkingu á áhrifum lífbrjótanlegs plasts á umhverfið, á meðhöndlun úrgangs og endurvinnslu. 


\section{Að̃ efla pekkingu á skaðlegum efnum sem notuð eru við endurvinnslu plasts}

Plastvörur og umbúðir kunna að innihalda efni sem eru skaðleg heilsu manna og umhverfinu, og sem kann að vera bannað að nota í tilteknar vörur, t.d. matarumbúðir eða barnaleikföng. Slík efni eða aukefni eru eldtefjandi efni, fastlitarefni, fylliefni, efni sem pola útfjólubláa geislun, mýkiefni og bindiefni sem notuð eru til að ná fram eða bæta eiginleika vörunnar og draga úr framleiðslukostnaði. Jafnvel pó að slík efni séu ekki skaðleg frá umhverfislegu sjónarmiði kunna pau að hamla endurvinnslu plastsins.

Reikna parf með pessum skaðlegu efnum og takmörkunum á notkun peirra til að tryggja að aðgerðir til að auka umfang endurvinnslu á plasti valdi ekki váhrifum af gáleysi, gegnum notkun á endurunnu plasti í nýjar vörur. Pað er bví mikil áskorun fyrir hingrásarhagkerfi sem byggir á hágæða hráefni og eiturefnalausri hringrás efnis að eiga við skaðleg innihaldsefni.

\section{Markmið 15}

Norræna áætlunin um að̃ draga úr umhverfisáhrifum plasts stuð̌lar að auknum upplýsingum um skaðleg innihaldsefni í plasti til að efla próun markvissra og hagkvæmra að̆gerða til að eiga við skaðleg innihaldsefni í hringrásarhagkerfi plasts.

\section{Markmið 16}

Norræna áætlunin um að draga úr umhverfisáhrifum plasts eflir lausnir sem tryggja að farið sé með plast, sem ekki er talið henta til endurvinnslu vegna skaðlegra innihaldsefna, á viðeigandi og öruggan hátt.

Pað er pví mikil áskorun fyrir hingrásarhagkerfi sem byggir á hágæða hráefni og eiturefnalausri hringrás efnis að eiga við skaðleg innihaldsefni. 



\section{$\mathbb{1}$}

Norræena ráŏherranefndin

Ved Stranden 18

DK-1061 København K

www.norden.org

\section{Útdráttur úr plastáætluninni:}

Norræna áætlunin um aô draga úr umhverfisáhrifum plasts er stefnumótunartæki til aô auka pekkingu, leggja drög að að̆gerðum og stuð̃la að samlegðaráhrifum, samstarfsnetum og vitundarvakningu á Norơurlöndum. Áætlunin mun styðjja við̋ norrænu löndin í við̋leitni peirra til að̃ fyrirbyggja myndun plastúrgangs, auka endurnotkun og endurvinnslu á plasti, greið̃a fyrir innleiðingu hringrásarhagkerfis og halda plastúrgangi og plastögnum í umhverfi sjávar í lágmarki. Áætlunin tekur til tímabilsins 2017-2018 og henni verður hrint í framkvæmd innan ramma Norrænu ráǒherranefndarinnar. 